\title{
The Gaps and Lessons of Ethiopian Share Company Governance in Light of International Company Model Laws
}

\author{
1.Tamiru Aboma* 2. Lamessa Gudeta Guder** \\ *Lega Attorney at Ethio-Telecom \\ **Western Showa Zone Attorney Office \\ Ambo, Ethiopia
}

\begin{abstract}
The proper governance of companies will become as crucial to the world economy as the proper governance of countries. It is the interaction between various participants (Shareholder, Board of Director and Company Management) in shaping corporation's performance and the way it is proceeding towards. Besides, it is the system by which companies are directed and controlled. Thus, corporate governance requires a legal and regulatory framework which is strong in order to attract investors to invest their capital in a company or organization. This development of corporation makes the requirement of good corporate governance inevitable in the modern corporate business. Coming to the corporate governance under Ethiopian commercial code, the law recognizes board of directors, shareholders meeting and auditors as the three principal organs of management. However, the law is criticized for its inadequacy of ensuring the interests and rights of shareholders (for instance, it does not adequately address the issues of basic ownership rights and there is also a fusion of power on single individual which opens the way to abuse the assets of a share company to the detriment of the shareholders), and other stakeholders to cope with the need of the prevailing corporate issues in the country. Accordingly, as to there is an increasing in number of share companies and their potential contribution to the economy of Ethiopia, such development will be sustainable only when it is supported by adequate legal and sound corporate governance. It will be shown that Ethiopia's corporate governance rules should be updated in order to increase the growth of companies and protect the interests of stakeholders. When a country revises its laws, it is an inevitable to look at laws and policies of advanced economies. In this regard the thesis critically analysis the Ethiopian share company governance with the OECD principles of corporate governance and EMCA general principles.
\end{abstract}

Keywords: Corporate Governance, Share Companies, Organs of Governance, OECD, EMCA and Basic Ownership Rights of Shareholders.

DOI: $10.7176 / \mathrm{JAAS} / 71-03$

Publication date: April $30^{\text {th }} 2021$

\section{INTRODUCTION}

The world has observed a substantial transformation in the role of the corporate sector in economic development and job creation. As corporations create jobs, generate tax income, produce a wide range of goods and services at reasonable prices. Within growing reliance worldwide on the corporate sector, the issue of corporate governance importance has similarly risen. This has been true for several years within OECD countries, ${ }^{1}$ where a great deal of work has taken place to improve corporate governance regimes.

Due to recent global financial crises ( for instance, in Asia) caused partly by non-optimal corporate governance practices by firms, the concept of corporate governance has become a worldwide subject of interest to both business decision and academicians. ${ }^{2}$ The massive losses recorded by most financial firms which almost caused a break down in the financial system and led to a recession brought into bright the importance of corporate governance practices. ${ }^{3}$ Corporate governance relates to the internal means by which corporations are operated and controlled.

In reaction to the growing cognizance of the importance of good corporate governance, the OECD was asked by Ministers in 1998 to develop a set of standards and guidelines for presentation to Ministers in May 1999. ${ }^{4}$ In this regard the OECD Principles signify the first initiative by an inter-governmental organization to develop the core elements of a good corporate governance regime. As a result, the Principles can be used as a yardstick by governments as they assess and improve their laws and regulations.

\footnotetext{
${ }^{1}$ OECD Principles of Corporate Governance, Meeting of the OECD Council at Ministerial Level, (1999)

${ }^{2}$ Berle, A. and G. Means, The modern corporation and private property, MacMillan, New York,

${ }^{3}$ S. Gyamerah, Listed International Journal of Advanced Multidisciplinary Research Volume 3, Issue 11 -2016

${ }^{4}$ To fulfil the Ministerial mandate, the OECD established an Ad-Hoc Task Force, comprised of all Member governments; the European Commission; four international organizations (such as the World Bank, International Monetary Fund, Basle Committee on Banking Supervision, and the International Organization of Securities Commissions); the OECD's Business and Industry Advisory Committee (BIAC) and Trade Union Advisory Committee (TUAC); and representatives from selected other private sector organizations.
} 
The Principles are envisioned to assist both member and non-member governments in their efforts to improve the legal, institutional and regulatory framework for corporate governance in their countries, and to provide guidance and suggestions for stock exchanges, investors, corporations, and other parties that have a role in the process of developing good corporate governance. The Principles are intended to be concise, understandable and accessible to the international community. The Principles purpose is to serve as a reference point. They can be used by policy makers, as they examine and develop their legal and regulatory frameworks for corporate governance that reflect their own economic, social, legal and cultural circumstances, and by market participants as they develop their own practices.

The European Model Company Act (EMCA) ${ }^{1}$ is designed as a free-standing general company statute that can be enacted by member States either substantially in its entirety or by the adoption of selected provisions. The objective of the EMCA design is to establish, on a solid scientific foundation, a new way forward in European company law inspired by the US Model Business Corporation Act. It offers the member States a harmonized company law but leaves it to each member state to decide whether it will offer its businesses the advantages given by harmonization. ${ }^{2}$

The EMCA can promote regulatory competition and it can also act as a tool for a harmonization of, and convergence between, member states' company laws. The EMCA can be regarded as a tool for better regulation ${ }^{3}$ in the EU since it provides a coherent, dynamic and responsive European legislative framework. Member States can benefit from using the Model Act as a company law paradigm, as it will be a modern competitive Company Act.

The creation of companies in the modern legal form is a current history in Ethiopia. To regulate these companies, Ethiopia legislated the 1931 Company and Bankruptcy Law. ${ }^{4}$ Nevertheless, the rapid growth of the sector in large scale and increased flow of foreign investment forced Ethiopia to enact a new commercial law which has its own inadequacy compared to the modern international company law. As a result, Ethiopia repealed the 1931 Company and Bankruptcy Law and enacted the 1960 Commercial Code. ${ }^{5}$ It precast from the French Commercial Code and drafted by Professor Jean Escarra, a French legal scholar. ${ }^{6}$ In Ethiopia, the formation of companies through the offering of shares to the public under the share company law provisions are intensely increasing. ${ }^{7}$ The Ethiopian Commercial Code provides two forms of companies named Share Company and private limited company. ${ }^{8}$ The two companies in Ethiopia have distinct features as regards formation, ways of raising capital, share transfer, company management, and the like. The Ethiopian share company roughly corresponds to the English public limited company, the publicly held corporation of the US. ${ }^{9}$

According to English Company Act section 1(3) of 1985, public company is a company limited by share or limited by guarantee and having a share capital. ${ }^{10}$ Further, a public company is one whose memorandum of association proposes to operate as a public company and must have been registered as "public limited" company and is to be identified as "PLC". ${ }^{11}$ It is also a company whose shares are traded on the stock exchange and invitation can be made to the public for subscription of shares or debentures, transfer of shares and acceptance of public deposits.

In the US, publicly held corporation is a corporation whose shares are generally available to public investors. ${ }^{12}$ All the shareholders of publicly held corporation are simply investors who are not concerned in the management activities of the corporation. ${ }^{13}$ Although the directors of publicly held corporation may own shares of the corporation, the corporation tends to be managed by professional managers. ${ }^{14}$ In effect, it offers investors to enter or exit merely by buying and selling their respective shares.

\section{Statement of the Problem}

In the contemporary world, the existences of appropriate and effective legal, regulatory and institutional foundations are pillars for a given country's comprehensive corporate governance framework. This in turn develops market integrity, improves economic efficiency and growth as well as it builds the investors'

\footnotetext{
${ }^{1}$ The European Model Companies Act (EMCA), 2015

${ }^{2}$ Ibid.

${ }^{3}$ Modernizing Company Law and Enhancing Corporate Governance in the European Union - A Plan to Move Forward, (2003).

${ }^{4}$ Getahun Seifu, 'Revisiting Company Law the Advent of Ethiopian Commodity Exchange’ 4(1) Mizan Law Review, (2010), pp.102-103

${ }^{5}$ Commercial Code of the Emperor of Ethiopia, 1960, Neg. Gaz, year 9 ${ }^{\text {th }}$, No.3, Proclamation No.166 of 1960.

${ }^{6}$ Paul Brietzke, 'Private Law in Ethiopia', 18 (2) Journal of African Law, (1974), pp.149,163

${ }^{7}$ Fekadu Petros Gebremeskel, 'Emerging Separation of Ownership and Control in Ethiopia Share Companies: Legal and Policy Implications' 4(1) Mizan Law Review 1, (2010), p.14.

${ }^{8}$ Supra note 9, Art. 212 (e) \& (f)

${ }^{9}$ Booz A. Hamilton, Ethiopia Commercial Law and Institutional Reform and Trade Diagnostic, USAID, (Jan 2007$)$, p. 18.

${ }^{10}$ Janet Dine, Company Law ( $5^{\text {th }}$ ed.), Pal grave Macmillan, (2005), p.11

${ }^{11}$ Stephen Griffin, Economy and Law: Fundamental Principles (3 ${ }^{\text {rd }}$ ed.) Pearson Edu. Limited, (2000), p. 49

${ }_{12}$ M. B. Metzger, Business Law and the Regulatory Environment: concepts and cases ( $8^{\text {th }}$ ed.) Irwin Inc., USA, (2002), P. 899

${ }^{13}$ Ibid.

${ }^{14}$ Ibid.
} 
confidence. In this regard Ethiopia has enacted its commercial code in 1960 and accordingly, the share company law comprises several provisions (205 Articles). The 1960 Commercial Code of Ethiopia has many provisions on how a Share Company is managed. ${ }^{1}$ As a result, the followings are widely accepted organs of management in a Share Company who have a role of management. These are shareholders meeting, board of directors and auditors. However, the legal problem in relation to management of share Company is that the commercial Code allows one and the same person to hold the post of board of directors, ${ }^{2}$ Chairman of the board, ${ }^{3}$ Chairman of the meeting. ${ }^{4}$ From this we can understand that, the Ethiopian Commercial Code allows one and the same person to hold different powers at the same time in the management organ. This kind of fusion of power by single individual opens the way to abuse the assets of a Share Company.

Furthermore, even though the share company law of Ethiopia has relevant provisions, it is unable to create conducive legal and regulatory environments to the smooth running and ongoing operation of share companies. Its legal and regulatory frameworks are not properly expressed and failed to provide comprehensive legislative response to the modern corporate governance issues of share companies.

For instance, the basic governance aspects of share company law provisions concerning shareholders are defective and inadequate. In this regard the followings are the major gaps and shortages that observed from it. The commercial code allows restriction of shareholder's rights to transfer of their shares either in the articles of association or by resolution of an extraordinary meeting. ${ }^{5}$ This does not mean that it only restricts the free transfers of sharers but it also subject assignment of shares to the approvals of boards. It also failed to disclose the relevant information like the voting procedures, the agenda of the meeting and the issues to be decided at the meetings for the shareholders. Additionally, the means of an accessing company's information provided under the commercial code ${ }^{6}$ are expensive for shareholders.

In the same way, the Ethiopian share company law failed to provide to minority shareholders the right to derivative actions against the directors in case their rights are violated. Even though, the share company law set the rule for the right of withdrawal from the company there is no provision for secondary market. If someone wants to sell his share in a company, there is no market for it at all. The shareholders also have no opportunity to ask questions the board of directors in case they are exercising of their right to participation and no means of voting other than in person. The share company law ${ }^{7}$ also entirely disregarded and failed to address the interests and roles of stakeholders (such as employees, suppliers, customers, the community) within the company.

Regarding the auditors, the basic functions of auditors are related to confirming or certifying the truthfulness of financial document of a Share Company. However, the Commercial Code does not show any kind of standard from auditors in their duty of confirming financial document.

Generally, the Ethiopian share company law provisions are complained about their legal inadequacy to accommodate the interests and concerns of the Ethiopian business community and in addressing the recently high developing company issues. ${ }^{8}$ The researcher shares this idea concerning the governance aspects of share company law.

Therefore, the above-mentioned problems inspired the researcher in order to access the need of international company model law for the case of Ethiopian share company governance.

\section{Research Questions}

Does the Ethiopian share company law adequately address the issues of share company governance? From this fundamental research question, this study has deduced the following specific research questions:

* Does the Ethiopian share company law is defective, inadequate and unable to provide comprehensively legislative response to the modern governance issues of share company?

* Do the OECD principles of corporate governance and EMCA general principles helps to solve the identified Ethiopian legal problems of share company governance?

* What lessons can be achieved from the International Company Model Law Principles for Ethiopian share company governance law?

\section{Objective of the Study}

\subsection{General Objective}

The over-all objective of the study would be:

* To assess the Ethiopian Share Company Governance Law in light of International Company Model

\footnotetext{
${ }^{1}$ Supra note 9, Arts. 347- 428

${ }^{2}$ Ibid, Art. 347(1)

${ }^{3}$ Ibid, Art. 348(1)

${ }^{4}$ Ibid, Arts. 404(1), 411(1), 412 \& 413

${ }^{5}$ Ibid, Art. 333

${ }^{6}$ Ibid, Arts. 392(3), 406, 417, 422 \& 427

${ }^{7} \mathrm{Ibid}$, Arts. 362-363

${ }^{8}$ Gebeyaw Simachew, A Critical Analysis of the Ethiopian Commercial Code in Light of OECD Principles of Corporate Governance, (2012)
} 
Laws (OECD Principles of corporate governance and EMCA general principles).

\subsection{Specific Objective}

The specific objectives of the thesis would be able:

* To assesses and carefully examine the legal problems of share company governance enshrined in the Commercial Code of Ethiopia.

* To examine whether the OECD principles of corporate governance and EMCA general principles may assist to solve the legal problems of share company governance in Ethiopia and

* To critically analysis the gaps and lessons of Ethiopian share company governance considering the international benchmark.

\section{Significance of the Study}

The study will focus on the problems of the Ethiopian share company governance and the suggested solutions. Hence, it may hopefully contribute much for the forthcoming of the Commercial Code of the country with respect to management of share company.

The outcome of this research paper has the following significances: It will have certain contributions for the legislative body. The research reminds to the Federal Attorney General (particularly to the drafting committee) as to it would be better if they consider the relevant OECD principles of corporate governance and EMCA general principles to facilitate the current business and rectify the existing problems of the Ethiopian share company management. The research also can have a significance to create awareness about the existing problems of share company management between shareholders, directors and the stakeholders at large. The study will also serve as a basis and may call the attention of those who want to conduct further research in the field. Finally, it may serve as a reference material in the academic sphere.

\section{Literature Review}

Some academic works have been published on company law in general and corporate governance by Ethiopian scholars. Hussein Ahmed Tura ${ }^{1}$ observes that the legal framework governing company governance in Ethiopia does not sufficiently address issues related to the roles, composition and remuneration of boards of directors in share companies. The relevant provisions of law do not demarcate the difference between corporate management and corporate governance. The governance powers of nonexecutive directors are not clearly provided separately from the management duties of company executives. However, the author did not focus on the whole areas of share company management. He only focused on the Boards of Directors of share companies.

Minga Negash ${ }^{2}$ remarks that the importance of corporate governance in Ethiopia is unsatisfactory and notes that "the Commercial Code of Ethiopia does not provide adequate legislative response to complex governance issues. He also observes that the absence of separation of powers in the institutional settings of the country and weak corporate laws are serious vacuums for complying with international corporate governance standards.

Fekadu Petros Gebremeskel ${ }^{3}$ emphasizes the newly developing separation between ownership and control in Ethiopia due to the emergence of newer companies with several thousand shareholders who have no control over the company. In this regard, he shows the deficiency of the Commercial Code in protecting the rights of minority shareholders in the context of share companies. He also further addresses most of the issues in corporate governance related to board of directors. But he failed to address other issues under the share company management rather than mainly, those minority shareholder's protection and corporate governance issues which related to Board of directors only.

Gebeyaw Simachew ${ }^{4}$ also addressed the issues of Ethiopian share company law considering OECD principles of corporate governance framework. He discusses the issue of share company law in general. But this thesis is going to discuss specifically the management of share companies in a full-fledged under the Ethiopian commercial code considering both the OECD principles of corporate governance and EMCA general principles. This thesis takes the themes discussed in the abovementioned works further and makes a distinction by examining the Ethiopian share company management problems and comparatively analysis it with the international company model laws. It also argues that there is inadequacy in the share company management of Ethiopia and forwards recommendations of modernization to be needed. This thesis also tries to deal with issues of share company management broadly and the problems it has on the interest of Ethiopian business community by making specific reference to the international model company laws.

\footnotetext{
${ }^{1}$ Hussein Ahmed Tura, Overview of Corporate Governance in Ethiopia: The Role, Composition and Remuneration of Boards of Directors in Share Companies, Vol.6, No.1, (2012)

${ }^{2}$ Minga Negash, Corporate Governance and Ownership Structure: The Case of Ethiopia, Vol.5, No.1, (2013)

${ }^{3}$ Fikadu Petros, Emerging Separation of Ownership and Control in Ethiopian Share Companies: Legal and Policy Implications, Vol.4, No.1, (2010)

${ }^{4}$ Supra note 26
} 
Mostly, even if certain researches are conducted regarding the corporate governance of share companies of Ethiopia with the role, composition and remuneration of board of directors, ownership structure, or other aspects of share companies are dealt with, none of them addresses the share company management problems in a fullfledged way and issues of modernization to be included under the Ethiopian share company management laws in relation to the international company model laws. Therefore, it is very essential and timely in Ethiopia to observe the share company management problems, and further examine existing legal frame works concerning it with the international standard.

\section{Research Methodology}

The design of the research is doctrinal. The most common methodology employed in this undertaking is doctrinal or library-based research which is concerned with legal preposition and doctrines. It is a research into the law and legal concepts in which the sources of data are laws. It is also concerned with the analysis of the legal doctrine and how it was developed and applied. It is purely aimed at finding a specific statement of the law, or it is legal analysis with more complex logic and depth. Thus, it is doctrinal research design that seeks to find the answer to certain legal issues or questions in the dissertation.

The method emphasized in the investigation of the problems of the share company governance based on the Commercial Code of 1960 . The study will principally employ qualitative research approaches. The nature of the study demands acquiring deep knowledge of the subject matter and deep legislative analysis to assess the share company management in Ethiopia. The study is qualitative in that it will devote on the logical reasoning, opinions, justifications or logical arguments on legal provisions. Therefore, this study is purely a qualitative approach mainly based on the assessment of the existing legal instruments relating to Ethiopian share company management and reason out it.

Data will be collected from both primary and secondary sources. Primary sources may include Proclamation. The secondary sources are library, domestic and foreign literatures related with the study. Accordingly, the principal emphasis is bestowed to the critical analysis of share company management in Ethiopia. Therefore, different source materials largely secondary data such as books, articles, journals and commentaries are used.

Besides, comparative and analytical approaches will be employed in the study. Accordingly, the study will analyses and explain the corporate governance under the Ethiopian share company law and International company models for comparing the corporate governance and protection of the shareholders in the two places. A comparative study of share company governance law will be made with reference to the international company models. The inadequacies and deficiencies of the corporate governance including the issues of organs of companies' governance under the existing Ethiopian share company law will be identified considering international company model.

It will present a broad review of the literature on corporate governance and the theoretical framework of corporate governance. The theoretical framework enunciates the prerequisite for comparative study and the legal basis for the corporate governance. By studying the main theoretical frameworks, the researcher able to develop a critical analysis of corporate governance and the protection of shareholders in Ethiopian share company law and international company model laws.

Generally, the methodology employed in this work is a doctrinal design that analysis the share company governance of Ethiopia in perspective of international model company laws and analytical points of view. Best practice of international benchmark (OECD principles of corporate governance and EMCA general principles) will be utilized in such assessment.

\section{Scope of the Study}

The whole study focuses on the Ethiopian share company governance as stipulated under the Commercial Code of Ethiopia. It denotes the legal problems of share company governance under Ethiopian commercial code and tries to propose solutions to research questions. Besides it also tries to refer and share the experiences of international model company laws.

\section{Limitation of the Study}

The limited time available to accomplish the study restricted the researcher from consulting many books. Even though more attention should be focus on the practical aspect of the corporate governance and its practices in real business environment, due to the shortage of time the pragmatic aspect of study never being came into focus. 2. The Legal and Regulatory Framework

As discussed in chapter two of this thesis, the OECD Principles desire the corporate governance framework should promote transparent and efficient markets, be consistent with the rule of law and clearly articulate the division of responsibilities among different supervisory, regulatory and enforcement authorities. ${ }^{1}$ The

\footnotetext{
${ }^{1}$ OECD Principles of Corporate Governance Framework (Revised April 2004), Principle I
} 
government policy makers should know-how their legal, regulatory and institutional bases that ensure the effective and efficient corporate governance framework. ${ }^{1}$ It sets out broad principles for governments to follow when reviewing their corporate governance policy framework. Broad supporting principles have been developed covering effective and efficient implementation and enforcement, and the mechanisms which should be established for parties to protect their rights.

The principles suggested policy makers to formulate an adequate and comprehensive legislative response. It emphasizes on the ultimate economic outcomes and assess all alternative policy options that shape the proper functioning of markets. This means that, the designed corporate law and regulation should be cost effective and enforceable equitably with all market players. It also avoids contradictory and overlapping provisions or regulatory gaps. Generally, the principles advocate that the legal, regulatory and institutional framework of a country that shapes the corporate governance of companies should be familiar with the new developments of markets. In the contemporary world, the existences of appropriate and effective legal, regulatory and institutional foundations are pillars for a given country's comprehensive corporate governance framework which in turn develops market integrity, improves economic efficiency and growth as well as it creates the investors' confidence.

Nonetheless, the legal frameworks of some share company law provisions regarding the corporate governance failed to create incentives to market players and failed to encourage transparent and efficient markets. Although the share company law of Ethiopia has relevant provisions, it is unable to create conducive legal and regulatory environments to the smooth running and ongoing operation of share companies. Its legal and regulatory frameworks are not properly expressed and failed to provide comprehensive legislative response to the modern corporate governance issues of share companies. The basic governance aspects of share company law provisions are defective and inadequate.

To demonstrate these, the provisions restricting shareholder's rights to transfer of their shares ${ }^{2}$ and subject assignment of shares to the approvals of boards will affect the basic ownership rights of shareholder. However, the articles shall prescribe the way such transfer of shares will be made, and it may also contain bona fide and reasonable restrictions on the right of members to transfer their shares. But absolute restrictions on the rights of members to transfer their shares shall be ultra vires.

The share company law also failed to disclose the relevant information like the voting procedures, the agenda of the meeting and the issues to be decided at the meetings for the shareholders and the means of an accessing company's information provided are expensive for shareholders. ${ }^{3}$ Similarly, the share company law failed to provide to minority shareholders the right to derivative actions in case their rights are violated. Even though, the share company law set the rule for the right of withdrawal from the company there is no provision for secondary market. $\mathrm{It}^{4}$ also entirely disregarded and failed to address the interests and roles of stakeholders within the company.

Moreover, the Ethiopian Commercial Code has many provisions on how a Share Company is managed. ${ }^{5}$ However, the legal problem in relation to management of share Company is that the commercial Code allows one and the same person to hold different powers at the same time in the management organ. ${ }^{6}$ Auditors are not managing organs but in exceptional circumstances in case where there are no surviving directors they can manage the company. The basic functions of auditors are related to confirming or certifying the truthfulness of financial document of a Share Company. However, the Commercial Code does not show any kind of legal standard from auditors in their duty of confirming financial document.

The above analyses revealed that the Ethiopian share company law provisions regarding the management aspects are criticized about their legal inadequacy to accommodate the interests and concerns of the Ethiopian business community and in promoting effective corporate governance. The same problems are also continued even under the draft commercial code. It would be better if Ethiopia has taken a lesson from the OECD principles of corporate governance that may support to solve such legal problems of the share company management in the amendment of its commercial code.

\subsection{Basic Rights of Shareholders}

The Ethiopian share company law provisions demonstrate the basic rights of shareholders. These are: right to information, right to participate and vote at the shareholders' meetings, right to share the profits or proceeds of the company, right to transfer of shares or withdraw from the company. These ownership rights of shareholders are almost like the OECD Principles discussed above in chapter two. However, all these basic ownership rights of shareholders are not appropriately expressed as under the OECD except the rights to share the profits of the

\footnotetext{
${ }^{1}$ The Methodology for Assessing the Implementation of the OECD Principles of Corporate Governance (2006)

${ }^{2}$ Supra note 9 , Art. 333

${ }^{3}$ Ibid, Arts. 392(3), 406, 417, 422 \& 427

${ }^{4}$ Ibid, Arts. 362-363

${ }^{5}$ Ibid, Arts. 347-428

${ }^{6}$ Ibid, Arts. 347(1), 348(1), 404(1), 411(1), 412 \& 413
} 
company.

Right to information's are the main tool for shareholders to make informed decisions in shareholders meeting. However, as noted in chapter three of this thesis, the means and accuracy of information disclosed to shareholders meeting are deficient and inadequate. The means of accessing company's information provided under commercial code and the new draft commercial code are very expensive for shareholders. The share company law also failed to require the disclosure of relevant information such as, voting procedures, the agenda of the meeting and the issues to be decided at the meetings. ${ }^{1}$

However, under the OECD, shareholders should be sufficiently informed on the decisions concerning fundamental corporate changes such as: amendments to the statutes, or articles of incorporation or similar governing documents of the company; the authorization of additional shares; and extraordinary transactions, including the transfer of all or substantially all assets, that in effect result in the sale of the company. ${ }^{2}$ Shareholders should have the opportunity to participate effectively and vote in general shareholder meetings and should be informed of the rules, including voting procedures, that govern general shareholder meetings. Hence, prior to the meetings, shareholders should also be furnished with enough and timely information concerning the date, location and agenda of general meetings, as well as full and timely information regarding the issues to be decided at the meeting. ${ }^{3}$

Regarding the shareholders right to information under EMCA, upon the request from a shareholder and when the board of directors/the management board consider it does not cause material damage to the company or, be contrary to law, they shall disclose to the general meeting the relevant information at the meeting in respect of any circumstances which may affect the evaluation of a matter on the agenda. ${ }^{4}$ Further, a shareholder shall be entitled to propose specific issues for inclusion on the agenda of the general meeting. ${ }^{5}$

The right to participation in general shareholder meetings is a fundamental right of all shareholders, both foreign and domestic, that is critical to their ability to influence the company. The procedures for notification of shareholder meetings and for casting votes should be designed to facilitate and encourage participation. This requires, timely notification and voting systems that enable shareholders to engage in the decision-making process at reasonable cost.

Shareholders voting rights are the key tools for shareholders to influence the company by participating and voting in the meetings of shareholders. They are entitled to appoint or remove directors (one areas of shareholders control are, control over management which refers to appointment, removal, change of directors or personnel's and shareholders may at any time and for any reason by ordinary majority remove any or all of the directors from office) and auditors; determine the amount of directors' remuneration and review their transactions with the company; pass resolutions to institute proceedings against liable directors; vote on the amendments of company's statutes and approve the changes made on classes of shares by class holders. But the shareholders have no opportunity to ask questions the board of directors and no other means of voting in case of absentia.

But, under the OCED shareholders should have the opportunity to ask questions to the board and they should be able to vote in person or in absentia, and equal effect should be given to votes whether cast in person or in absentia. ${ }^{6}$ The EMCA gives shareholders fundamental rights at general meeting. ${ }^{7}$ It secures that all shareholders may participate in general meetings. This includes the right to speak, to vote, to make proposals, and to ask questions and even if the shares do not have voting rights the shareholders may attend the general meeting and make use of all other shareholder rights. ${ }^{8}$ EMCA ensures that shareholders have and take the opportunity to attend and vote at the meetings by allowing for electronic general meetings. ${ }^{9}$ This allowing member States to permit companies to offer to their shareholders any form of participation in the general meeting by electronic means, and generally the efforts engage shareholders in the general meeting's decision process. This is important particularly regarding the growing number of international investors. Electronic participation is especially used in large companies, but they also consider that all companies should be allowed to make use of electronic general meetings. Especially in small companies with few shareholders "written general meetings" is often used. ${ }^{10}$

Institutional investors under the commercial code have voting rights through proxies. ${ }^{11}$ However, they may

\footnotetext{
${ }^{1}$ Ibid, Art. 396

${ }^{2}$ Supra note 35, Principle II (B) and Angel Gurria, G20/OECD Principles of Corporate Governance, (OECD Secretary-general, Sep. 2015)

${ }^{3}$ Ibid, Principle II C (1)

${ }^{4}$ Supra note 5, Chapter 11, Section 23.

${ }_{6}^{5}$ Ibid, Section 13.

${ }^{6}$ Supra note 35, Principle II C (2 \& 4)

${ }^{7}$ Supra note 5, Chapter 11, Section 6 (1)

${ }^{8}$ Ibid.

${ }^{9}$ Ibid, Chapter 11, Section 5

${ }^{10} \mathrm{Ibid}$, Section 2

${ }^{11}$ Supra note 9, Arts. 328, 329 and 398(2)
} 
not exercise their right to vote where their interests are in conflict with the company. ${ }^{1}$ On the other hand, the OECD Principles promote institutional investors to vote in meetings of shareholders with the prerequisites of disclosing their overall corporate governance, voting policies with respect to their investments, including procedures, and how they manage material conflicts of interest that may affect the exercise of ownership rights regarding their investments. ${ }^{2}$

The right to transfer/sale of shares or withdraws is another basic ownership right of shareholders from the company. EMCA assumes that shares are freely transferable, in accordance with normal civil law (common law) rules on transfers of property and other real rights. At the same time, EMCA has no knowledge of convincing reasons for rules that would mandatorily limit the free transferability of shares. The issue is therefore left to the articles, which may limit free transferability. Any limitation on transferability will have to be expressly provided for in the articles, the memorandum or a separate document open to public inspection and is subject to the requirement on shares. This will help a subscriber for shares of limited transferability, should have full knowledge of this fact at the time the company is formed. However, if a public company is publicly traded, securities regulation demands that the shares are freely transferable.

Contradictory to this rule, the commercial code and its draft one allows the company's statutes (articles of association) or resolutions of extraordinary meeting restricting the free transfers of sharers and it also subject assignment of shares with the consent of the board of directors except in case a right of preemption is reserved to the company or shareholders and the conditions relating to the exercise of the right of preemption are specified and the price of preemption is fixed. ${ }^{3}$ These restrictions limit the shareholders exercise of their basic ownership rights. Hence, the existence of this provision in the share company law is unachievable with the distinct features of public companies. In addition, the approval of boards on the assignment of shares as a legal requirement is also another burdensome.

\subsection{Treatments of Shareholders and Protections of Minority Shareholders}

The Ethiopian share company law suggests some relevant provisions regarding the equitable treatments and protection of minority shareholders. All shares of the same class shall have the same rights and any modification of the rights of a class of shareholders by a resolution of a general meeting becomes effective only when confirmed by a special meeting of the shareholders in the class concerned. ${ }^{4}$ This is comparable with EMCA and OECD, in which all shares shall carry equal rights in the company, unless otherwise provided in the articles of association $^{5}$ and all shareholders of the same series of a class should be treated equally and any changes in voting rights should be subject to approval by those classes of shares who are negatively affected. ${ }^{6}$

Shareholders have the right to amendments of the company's statutes (the memorandum or articles of association) through majority or unanimous vote. ${ }^{7}$ They have the right to withdraw from the company subject to prescribed preconditions. Shareholders representing one tenth of the share capitals of the company have also the right to call shareholders general meetings. ${ }^{8}$ In case where there are several groups of shareholders having different legal status the articles of association provide for each group to have the right to elect at least one representative as a board member ${ }^{9}$ and shareholders having not less than $20 \%$ of share capitals of the company have also the right to appoint one auditor. ${ }^{10}$

For boards to improve the company's efficiency and solid financial markets, the share company law provisions should be strengthened in providing adequate basic ownership rights of shareholders as a precondition. In these cases, many companies in OECD countries are seeking to develop better channels of communication and decision-making with shareholders. Efforts by companies to remove artificial barriers to participation in general meetings are encouraged and the corporate governance framework should facilitate the use of electronic voting in absentia. shareholders voting rights should be extended by mail, custodian or nominee of shares. ${ }^{11}$

In case misuse of companies' assets by majority shareholders to the detriment of minority shareholders and the company, the share company law provisions failed to adequately protect minority shareholders from corporate insiders and abusive self-dealings by the interests of majority shareholders. Insider trading and abusive self-dealing activities should be prohibited under the OECD. ${ }^{12}$ Therefore, the share company law must provide legal protections to minority shareholders through imposing fiduciary duties on controlling shareholders and

\footnotetext{
${ }^{1}$ Ibid, Art. 409(1)

${ }^{2}$ Supra note 35 , Principle II, F (1\&2)

${ }^{3}$ Supra note 9 , Art. 333

${ }^{4}$ Ibid, Arts. 335 and 426

${ }^{5}$ Supra note 5, Section 9

${ }^{6}$ Supra note 35 , principle III (A (1))

${ }^{7}$ Supra note 9 , Arts. 423-425

${ }^{8}$ Ibid, Art. 391(2)

${ }^{9}$ Ibid, Art. 352

${ }^{10}$ Ibid, Art. 368(2)

${ }^{11}$ Supra note 35, Principles III, A (3 and 5)

${ }^{12}$ Ibid 1 , principle III (B)
} 
requiring review of their transactions with the company. ${ }^{1}$

The EMCA shares the view that company law, including the chapter on general meetings, should encourage the shareholders to be active and improve their possibilities to act as the company's highest decision-making body which also stated in the EMCA in the general principle of shareholder democracy. ${ }^{2}$ The method of the EMCA is that the general meeting must decide on important decisions which concern the company, and this should be expressed by mandatory provisions in the chapter on general meeting as well as in other chapters of the EMCA. Further, the Articles of association may decide that certain decisions may only be taken by the general meeting. Shareholders should have the right to set any other issues on the agenda of extraordinary meetings.

For shareholders to play an active role in the company, they must have the opportunity to participate in the general meeting. Incentives are needed to ensure and facilitate that shareholders participate actively at the general meetings. EMCA to ensure that shareholders have and take the opportunity to attend and vote at the meetings by allowing for electronic general meetings, use of proxies. The general meeting rules are made flexible in order to secure shareholders' interest in formal general meetings and at the same time allow shareholders to decide on company matters without unnecessary bureaucracy ${ }^{3}$ for instance, to allow general meetings to take place without complying with the requirements of form and notice.

They also considered which means for minority protection should be included in the EMCA and accordingly it include provisions on decisions which should be taken with a super majority or even unanimously. ${ }^{4}$ Any proposed resolution to amend the articles of association must be passed by at least two-thirds of the votes cast as well as at least two-thirds of the share capital represented at the general meeting. ${ }^{5}$ All member states' companies' acts which demand a qualified majority to change the articles of associations, include provisions on changing of the articles of association. EMCA distinguish between general changes of the articles of association ${ }^{6}$ and specific changes which demand a higher majority. ${ }^{7}$ The dual requirement (qualified majority of both the votes casted and the share represented) is chosen in order to protect the interest of shareholders with limited voting rights.

Any proposed resolution to amend the articles of association and increase shareholder obligations to the limited liability company requires the unanimous agreement of all shareholders. ${ }^{8}$ Most Member States require a higher majority for several specific changes of the Articles or even demand for unanimous decisions. The General Meeting may not pass a resolution which obviously is likely to give certain shareholders or others an undue advantage over other shareholders of the company. ${ }^{9}$ The principle of shareholders equal rights is included in the general provision on minority protection. It is a fundamental company law principle that all shares in same position enjoy equal rights in the company.

The share company law prohibits directors' loans and any business transaction with the company directly or indirectly requires a prior approval of boards and notice shall be given to the auditors. ${ }^{10}$ However, the share company law failed to provide to minority shareholders rights to derivative actions against the directors or controlling shareholders' resolutions or third parties on behalf of the company in case their rights are violated. As indicated under chapter three with the liabilities of the directors in Ethiopian share companies, neither individual shareholders nor minority shareholders can bring a derivative suit. ${ }^{11}$ Thus it shows that the derivative suit right of an individual shareholder or minority shareholders is not recognized in Ethiopian share company law. Minority shareholders should be protected from abusive actions by, or in the interest of, controlling shareholders acting either directly or indirectly, and should have effective means of redress. ${ }^{12}$

Regarding minority shareholders, the Ethiopian commercial code neither clearly defines minority nor explicitly refer to the rights of minority shareholders. Rather their protections are found in scattered provisions of the share company's governance. For instance, the commercial code of Ethiopia is authorizing the minority shareholders to call meetings of shareholders and enabling them to put agenda for resolution at shareholders' meetings.

The right to exit or withdraw is one legal stage to avoid the oppression of minority by the majority. The right to withdraw is the basic right that cannot be restricted by the articles of association under the Ethiopian

\footnotetext{
${ }^{1}$ OECD: 'Related Party Transactions and Minority Shareholder Right.' (2012)

${ }^{2}$ Supra note 5, Chapter 1, Section 12

${ }^{3}$ Ibid, Chapter 11

${ }^{4}$ Louis Bouchez, 'Principles of Corporate Governance: the OECD Perspective' (2007) 4(3) European Company Law.

${ }^{5}$ Supra note 5, Section 29

${ }^{6}$ Ibid.

${ }^{7}$ Ibid, Section 30

${ }^{8}$ Ibid.

${ }^{9}$ Ibid, Section 31

${ }^{10}$ Supra note 9, Arts. 356(1) and 357(1)

${ }^{11}$ Ibid, Art. 365

${ }^{12}$ Supra note 35 , Principles III, A (2)
} 
commercial code. ${ }^{1}$ The restriction of such right in the articles of association is void. If the minority shareholders don't want to continue with the company due to the significance change in the nature and object of the company, transfer of the head of the company they have the right to exit. ${ }^{2}$

\subsection{Interests and Roles of Stakeholders}

Regarding the incorporation of stakeholders into the management of the company, there are two competing models of corporate governance i.e. the shareholder ship and the stakeholder ship models. ${ }^{3}$ The Anglo-American Corporate Governance system is based on the Shareholder ship Model while the European corporate governance System is based on the German's Stakeholder ship model.

According to the shareholder model the objective of the firm is to maximize shareholder wealth through allocative, productive and dynamic efficiency i.e. the objective of the firm is to maximize profits. Therefore, managers and directors have an implicit obligation to ensure that firms are run in the interests of shareholders. Boards and companies' managers should direct the company for the sole interests of maximizing shareholders profit by disregarding the interests of stakeholders.

The stakeholder model takes a broader view of the firm. It claims that corporate governance is about directors and managements managing for stakeholders which involved attention to the interests and well-being of stakeholders than simply maximizing shareholder wealth. According to the traditional stakeholder model, the corporation is responsible to a wider constituency of stakeholders other than shareholders. ${ }^{4}$ Other stakeholders may include contractual partners such as employees, suppliers, customers, creditors, and social constituents such as members of the community in which the firm is located, environmental interests, local and national governments, and society at large.

Later these two competing approaches converge into another theory called an "enlightened shareholders value" approach in which the decisions of the board should bring into line the interest of shareholders profit maximization with the interest of stakeholders for the long-term profit maximization of shareholders and sustainability of the company. ${ }^{5}$

The corporate governance framework should recognize the rights of stakeholders established by law or through mutual agreements and encourage active co-operation between corporations and stakeholders in creating wealth, jobs, and the sustainability of financially sound enterprises. ${ }^{6}$ Corporations should recognize that the contributions of stakeholders constitute a valuable resource for building competitive and profitable companies. Because the competitiveness and ultimate success of a corporation is the result of teamwork that includes contributions from various of resource providers comprising investors, employees, creditors, and suppliers. The governance framework should recognize that the interests of the corporation are served by recognizing the interests of stakeholders and their contribution to the long-term success of the corporation. For the long-term profit maximization of shareholders and sustainability of the company, the decisions of the board should bring into line the interest of shareholders profit maximization with the interest of stakeholders. ${ }^{7}$

The United Kingdom Companies Act requires boards to promote the interests of stakeholders. ${ }^{8}$ Stakeholders are very important for organizations because they interact with the organization on a day to day basis hence, they have a very big influence on the affairs of the business. Where stakeholders participate in the corporate governance process, they should have the right to access to relevant, sufficient and reliable information on a timely and regular basis. ${ }^{9}$ The legal framework and process should be transparent and not impede the ability of stakeholders to communicate and to obtain redress for the violation of rights. ${ }^{10}$

Therefore, the OECD Principles recommended corporate governance frameworks should address the interests of stakeholders provided by laws and contracts. The principles particularly emphasized that to enhance companies' performances, employees should be allowed to engage in the corporate governance of the company. Participation of employees in corporate governance depends on national laws and may vary from company to company. The principles further advocate corporate governance frameworks are expected to have effective and efficient insolvency laws and strong enforcement of creditors' rights.

As discussed in chapter three, the share company law provisions entirely disregarded the interests of stakeholders within the company except rights of creditors. Only creditors of companies are permitted in certain

\footnotetext{
${ }^{1}$ Supra note 9, Art. 463

${ }^{2}$ Ibid.

${ }^{3}$ Kerry E. Howell, A Review of the two main competing models of corporate governance: The Shareholder ship Model versus the Stakeholder ship Model, Vol.5, Issues 1, (2007), p.9

${ }^{4}$ Freeman R., Strategic Management: A Stakeholder Approach, Cambridge, UK: Cambridge University Press

${ }^{5}$ Virginia Harper Ho, “Enlightened Shareholders Value": Corporate Governance Beyond the Shareholders and Stakeholders Divide' 36 Journal of Corporation, (2010), pp 60-62.

${ }^{6}$ Supra note 35, Principle IV

${ }^{7}$ Supra note 226

${ }^{8}$ Companies Act of 2006 (UK) Sections 172(1) provides companies' directors have the responsibility to promote the interests of employees, customers, suppliers and companies' operations effect on the community and the environments.

${ }^{9}$ Supra note 35 , Principle IV (D)

${ }^{10}$ Ibid, Principle IV (B)
} 
circumstances to participate and vote in meetings called by their representative.

Correspondingly, companies' directors are liable to creditors when they failed to preserve the assets of the company. ${ }^{1}$ Under the commercial code, directors are only accountability to the laws, shareholders and the company. ${ }^{2}$ The same is true under the draft commercial code. These provisions exclusively disregard and failed to address the interests of employees, suppliers, customers, the community and environments that are required by the current United Kingdom Companies Act of 2006 and OECD Principles IV. Thus, by taking into consideration the advantages that the stakeholders have in company, it would be better for Ethiopia take a lesson from both OECD principles and EMCA (UK Companies Act) while revising its share company governance law. The board should be responsible for ensuring that an appropriate connection takes place among the organization, its shareholders and other key stakeholders. The board should respect the interests of its shareholders and other key stakeholders within the context of its fundamental purpose.

\subsection{Board of Directors}

The board of directors is a corporation's governing body. It consists of a group of individuals elected by shareholders. The board of directors are responsible for setting company policy and overseeing the company's managers. A major theme of corporate governance is divorce of shareholders from their corporation resulted in the separation of ownership and control. The shareholders own the company, but the managers control the operations. The shareholders do not have a direct decision-making authority over their corporation. The day to day function of a corporation falls into the hands of few individuals. The board of directors is expected to try to align the interests of shareholders and managers. They need to always act in the best interest of the company. Under the company law in order to promote the well-being of company and protect the interest of shareholders' directors have the following duties. ${ }^{3}$

The duty to care: The duty care of director refers to the competence of directors. There two views regarding the duty to care: subjective standard view and objective standard view. ${ }^{4}$ However, there is a disagreement between scholars concerning the duty to care because some say it should be measured based on subjective and others say based on the objective standard. A subjective formulation is one that is specified by reference to what a person with the director's actual abilities can achieve. Failing to achieve has the defenses like lack of qualification/competence. on the other hand, an objective standard is formulated by reference to what a reasonable director in the position of the actual director could be expected to achieve in respective of what the actual director could achieve. In this situation, lack of qualification /competence is not a defense to liability for failing to achieve the reasonable standard.

Avoiding hindsight bias: it refers to avoiding excessive risk which means that any director always bear risk, but he must avoid excessive risk. In all decision making of the directors the business opportunities should be considered and the directors should take the risk and must be caution. Directors should do for the best interest of the company in good faith. In general, the decisions of the directors should be appropriate, rational and free of conflict of interests which is termed as "safe harbor" for directors" decision making.

Delegation: even though delegation is not any easy task, if the director become unfit the delegation is possible and it can be done by board of directors i.e. the internal control system. ${ }^{5}$

Duty to promote the success of the company: This refers to the director's core duty of loyalty and it applies to all activities of the directors. ${ }^{6}$ It is undoubtedly a fiduciary duty. Directors devotes their effort for both shareholders and stakeholders (customers, suppliers, supportive employees).

Duty to act within powers: It refers to the director's obligation to in accordance with the company's constitution. $^{7}$ The constitution provides the framework within which the directors are required to confine the exercise. The reason why directors are conferred to comply the company's constitution is that director's powers are derived from the articles of association. Almost all powers of directors of the company are provided under the article of association or memorandum of association. Acting for an improper purpose cannot be acceptable and admissible in company's day to day activity and a director who through improper causes harm to the company will be liable to reimburse the company for any lose caused to it.

Duty not to accept benefits from third party: The third party refers to the party that have some chain up on the company and benefits refers to any benefit attached to the chain of such third party. Because such issues create conflict of interest between the company and the director.

Further, as discussed under chapter two, the corporate governance framework should ensure the strategic guidance of the company, the effective monitoring of management by the board, and the board's accountability

\footnotetext{
${ }^{1}$ Supra note 9 , Art. 366(1)

2 Ibid, Arts. 362-364

${ }^{3}$ Paul Davies, Introduction to Company law, (2 ${ }^{\text {nd }}$ ed.), University of Oxford, (2010), pp.145-160 and A class lecture note on the Duties of Directors by Dr. Lamessa B. on the course of Advanced Company Law and Policy.

${ }^{4}$ Ibid, pp.150-153

${ }^{5}$ Ibid, p.153

${ }^{6}$ Ibid, p. 155

${ }^{7}$ Ibid, p. 157
} 
to the company and the shareholders. ${ }^{1}$ Companies are professionally managed and also subject to effective oversight by the board to prevent self-dealing and to ensure that the interests of the company and the shareholders are considered by both the board and the management.

In directing the company and overseeing the managements, board structures and procedures, some countries have mostly "two-tier" boards that separate the supervisory function and the management functions into different bodies i.e. a supervisory board composed of non-executive board members and a management board composed entirely of executives while other countries have "unitary" boards, which bring together executive and nonexecutive board members. There is also an additional statutory body for audit purposes in some countries.

The OECD principles are designed to apply to all board structures and advocate boards should perform in a fully informed basis, in good faith, with due diligence and care and in the best interest of the company and shareholders. ${ }^{2}$ In order to implement the "duty of care and loyalty" the principles recommended that where board decisions may affect different shareholder groups differently, the board should treat all shareholders fairly ${ }^{3}$ and the board should apply high ethical standards and should take into account the interests of company's stakeholders. $^{4}$

The board is mainly responsible for monitoring managerial performance and achieving an adequate return for shareholders, while preventing conflicts of interest and balancing competing demands on the company. The board has a duty to act in their best interests in addition to their accountability to the company and its shareholders. Board members are required to access accurate, material and timely information before making any decisions during discharging of their duties ${ }^{5}$ and they are expected to take due regard and deal fairly with other stakeholder interests.

Pursuant to the provisions in EMCA, the general meeting makes decisions on company matters and the directors execute such decisions of the general meeting. A director of a company has a duty of care in avoiding harm to the company, he must exercise reasonable care, skill and diligence i.e. directors shall have a duty to act with care and skill in the conduct of business and a duty of loyalty in placing the company's interests ahead of their own i.e. directors must act in good faith in order to promote the success of the company for the benefit of its members. Director should have regard to promote the interests of stakeholders. ${ }^{6}$ They also have the duty to avoid conflicts of interest. ${ }^{7}$

The EMCA allow companies to choose between different board structures, including a one-tier system, a two-tier system and a system in between. Most of the Member States apply the two-tier system in public companies which is in line with the trend that can be observed in the member states though there is no evidence that one system is better than the other. In most member states, there are two separate boards, the management board and the supervisory board. This ensures a separation between management board and the supervisory board which has the purpose to prevent conflict of interest and power concentration in the hands of one person through providing clear line of authority.

Coming to the commercial code the board of directors is the most important and key organ in the management of Share Company and is responsible for decision making in their major business and overseeing the general affairs of the company. However, the legal problem in relation to governance of share Company is that the commercial Code allows one and the same person to hold different powers at the same time in the management organ. ${ }^{8}$ It allows the same person to hold many powers and this kind of fusion of power paved the way for a person to exploit and abuse the assets of Share Company. This in turn affects the interests of shareholders do they have with their company and they do not want to come and invest in the company. Therefore, in order to avoid such legal problems and to guarantee the interests of those who want to invest in the share company without any fear, it should curb such legal gaps by observing model company law principles on the issue.

\subsection{Auditors}

As discussed under chapter two of the OECD principles, the corporate governance framework should ensure that timely and accurate disclosure is made on all material matters regarding the corporation, including the financial situation, performance, ownership, and governance of the company. ${ }^{9}$ Companies' disclosure is crucial for shareholders to exercise their ownership rights and for regulators to detect and fix illegal performs within companies. The principles dispose that the disclosed information should be prepared in "accordance with high

\footnotetext{
${ }^{1}$ Supra note 35 , Principle VI

${ }^{2}$ Ibid, Principle VI, A

${ }^{3}$ Ibid, Principle VI, B

${ }^{4}$ Ibid, Principle VI, C

${ }^{5}$ Ibid, Principle VI, F

${ }^{6}$ Companies Act of 2006(UK) Sections 172(1) provides companies' directors have the responsibility to promote the interests of employees, customers, suppliers and companies' operations effect on the community and the environments.

${ }^{7}$ Supra note 5, Chapter 9, 10 and 12 .

${ }^{8}$ Supra note 9, Arts. 347, 348, 404(1), 411(1), 412 \& 413

${ }^{9}$ Supra note 35 , Principle V
} 
quality financial and non-financial accounting standards" and audited by independent, competent and qualified external auditors. ${ }^{1}$ External auditors are accountable to shareholders and the company and owed fiduciary duties to their auditing professions. ${ }^{2}$

The duties of auditors are explicitly dealt with in supporting principles and include accountability to shareholders and a duty to the company to exercise due professional care in the conduct of the audit. Care should be given in ensuring auditor independence, including steps to manage and to minimize potential conflicts of interest. The ultimate responsibility for ensuring independent audit must be with the board and the means of disseminating the information should be equitable to all users in time and cost effective to access. ${ }^{3}$

Transparency and disclosure of the financial condition of companies is an important aspect of corporate governance. Disclosures in the form of auditing reports enables the investors to know if there were management errors of the company. ${ }^{4}$ As to the management is using investors' money for the benefit of company examination of the financial record is crucial. Mostly auditing is done by external auditors or accounting firms. An auditor has the function to guarantee the accuracy of reports by the management and it assesses and reports the overall economic condition of the company which results in the protection of company against fraudulent management. Auditors are one organ of corporate governance under commercial code as discussed under chapter three. As a rule, auditors are appointed by the general meetings of shareholders in the commercial code ${ }^{5}$ which allows a natural person or an accounting firm to be as an external auditor.

Auditors should avoid any conflict of interests in carrying out their tasks. The law avoids the potential conflict of interests by disqualifying certain persons from being appointed as auditors. For instance, founders of a company, shareholders who contributed in kind, directors and persons affiliated with or who receive salaries from such persons in relation to duties other than auditor ship cannot serve as auditors. ${ }^{6}$ The general meeting of shareholders is given with the power of dismissing auditors. ${ }^{7}$ Such reserving power to the shareholders helps them to avoid the directors from dismissing an auditor for the fear of their financial misconduct. Auditors are civilly and criminally liable for their intentional furnishing and confirming the false financial records of a company. ${ }^{8}$ Failure to disclose the misconducts of management and board of directors to the prosecution also entails liabilities. ${ }^{9}$

Even though the basic functions of auditors are related to confirming or certifying the truthfulness of financial document of a Share Company, the Commercial Code does not show any kind of standard from auditors in their duty of confirming financial document. Auditing standards provide a measure of audit quality and the objectives to be achieved in an audit. An independent auditor plans, conducts and reports the results of an audit in accordance with generally accepted auditing standards. Generally accepted auditing standards are a set of systematic guidelines used by auditors when conducting audits on companies' finances, ensuring the accuracy, consistency, and verifiability of auditors' actions and reports which comprises: $:^{10}$

"the examination is to be performed by a person or persons having adequate technical training and proficiency as an auditor; in all matters relating to an assignment, an independence in mental attitude is to be maintained by the auditor or auditors; due professional care is to be exercised in the performance of the audit and the preparation of the report; the auditor must obtain a sufficient understanding of the entity and its environment, including its internal control; the auditor must state in the auditor's report whether the financial statements are presented in accordance with generally accepted accounting principles; the auditor should clearly indicate the character of the auditor's work, if any, and the degree of responsibility the auditor is taking, in the auditor's report."

From the quoted statement one can understand that there must be standard that an auditor should follow in case of certifying the truthfulness of a financial document of a share company which one can hardly find under the Ethiopian share company law.

The commercial code is too silent as to a mere check of arithmetical accuracy of financial documents is adequate or not in order to conclude that there is a correct and accurate financial document. Hence, in the existence of such legal problems, it helps auditors to perform their task in an improper and dishonest manner. There is no other mechanism of controlling auditors under the commercial code except qualified inspector

\footnotetext{
Ibid, Principle V, B and C

${ }^{2}$ Ibid, Principle V, D

${ }^{3}$ Ibid, Principle V, E

${ }^{4}$ Jeans Jacques Du Plessis, Anil Hargovan and Mirko Bagaric, Principles of Contemporary Corporate Governance $\left(2^{\text {nd }}\right.$ ed. Cambridge University Press, New York 2011) pp. 341-342.

${ }_{6}^{5}$ Supra note 9 , Art. 368

${ }^{6} \mathrm{Ibid}$, Art. 370

${ }^{7}$ Ibid, Art. 371

${ }^{8}$ Ibid, Art. 380(1)

${ }^{9}$ Ibid, $380(2)$

${ }^{10} \mathrm{https}: / /$ www.investopedia.com/terms/g/gaas.asp, last visited on 14 May 2019.
} 
appointed by the ministry in case where there has been a resolution of general meeting or an order of the court. Thus, Ethiopia would take a lesson from the above-mentioned model company law to overcome the problems of an improper and dishonest act of auditors under the share company law.

\section{CONCLUSION AND RECOMMENDATION}

\subsection{Conclusion}

The commercial code of Ethiopia has many provisions on how a Share Company is governed. However, the law is unable to address share company governance issues regarding matters such as: Initially, concerning shareholders basic ownership rights like the decision-making rights, appointment rights and affiliation rights in the governance of share company; It restricts shareholder's rights to transfer of their shares as it clearly provides the concept of restriction on the free transferability of shares which contradicts with the distinctive feature of companies; It failed to disclose the relevant information like the voting procedures, the agenda of the meeting and the issues to be decided at the meetings and the means of an accessing company's information provided are also expensive for shareholders and It does not provide the right to derivative actions for minority shareholders in case their rights are violated.

Secondly, the is reluctant in addressing the interest and rights of other stakeholders who have relationships with companies that includes employees, creditors, suppliers, customers and communities. It is inevitable that, the continuous profit from corporate activities would not be generated without smooth relationships with these stakeholders. Nevertheless, the commercial code disregards and failed to address the interests and roles of such stakeholders within the company. Even if in certain circumstances it permits the company's creditors to protect their right in case where the director of the company fails to preserve intact the company's assets in an exceptional way, it totally disregarded the interest and rights of other stakeholders.

Thirdly, the law is criticized for allowing fusion of power. Because it allows the same person to hold different powers at the same time in the governance organ. Accordingly, there is the possibility of a single person can hold the position of board of director, chairman of the board and chairman of the meeting which in turn opens the way to abuse the assets of a Share Company to the detriment of the shareholders.

Furthermore, the modern company law provides generally accepted auditing standards when auditors conducts an auditing on companies' finances, ensuring the accuracy, consistency, and verifiability of auditors' actions and reports. However, the commercial code of Ethiopia does not show any kind of standard from auditors in their duty of confirming financial document.

The model company laws, OECD principles of corporate governance and EMCA general principles adequately recognized issues of basic ownership rights of shareholders such as transferability of shares, equal treatment of shareholders and minority protection, the right to participation and vote; the interest and rights of all stakeholders and it also clearly prohibits the concentration of power on the hand of single individual i.e. by following the two-tier board of style concerning corporate governance matters. This will ensure a separation of power between management by the executive board and governance by the supervisory board which has a purpose to prevent conflict of interest and power concentration in the hands of one person.

Accordingly, adopting both the OECD principles of corporate governance and EMCA general principles in Ethiopian commercial code particularly on the governance of share company law helps to solve the identified legal problems of Ethiopian share company governance and it can be considered as a lesson on the same.

\subsection{Recommendation}

Having thoroughly scrutinized the legal problems surrounding Share Companies governance in Ethiopia, the researcher would like to recommend the subsequent points.

* For shareholders effectively exercise their power such as the decision-making rights, appointment rights and affiliation rights in the governance of share company, it would be better if the existing legal inadequacy and gaps of shareholders basic rights can be resolved considering lessons from the OECD principles of corporate governance and the relevant EMCA general principles. Hence, Corporate governance for public companies should protect the rights of shareholders and it has also been structured with the primary focus on shareholders. Shareholders as the providers of the capital are at the core of corporate governance and they shall be authorized to exercise various rights in managing a company.

* The research recommends that it would be better if the corporate governance of Ethiopian share company law be amended in a way it recognizes the rights of all stakeholders and encourage their cooperation between corporations and stakeholders. Shortly to realize the interest and rights of stakeholders it is advisable that the Ethiopian share company law must follow an enlightened shareholders value approach. Accordingly, the interests of the corporation are more protected by recognizing the interests of stakeholders and their contribution to the long-term success of the corporation.

* The research recommends that, the forthcoming Commercial Code must be amended in a way it should 
prevent the problem of fusion of power in the governance of share companies, with respect to board of directors. This will ensure a separation of power between organs of share company governance which has a purpose to prevent conflict of interest and power concentration in the hands of one person.

* Even though the existing Commercial Code or the draft commercial code has allowed one and the same person to hold many powers, the researcher proposes two solutions. These are:

$\checkmark \quad$ First, shareholders of a company can avoid fusion of power by restricting a person's power as per the company's statute (through Article of Association).

$\checkmark$ Second, through issuing directive for all share companies it can be possible to avoid the problem of fusion of power on the same person. For instance, the NBE on Licensing and Supervision of Banking Business issued Directive No. SBB/39/2006 which is appropriate only for banks. According to this directive, number 5.1 .4 (ii) chairperson of board of directors of a bank shall not be chief executive officer of the same bank. This does mean that one and the same person is prohibited from being a Chairman of the board and Chief Executive Officer at the same time. Further it also prohibits a board member of a bank from being to serve as a board member of any other financial institution at the same time.

* Regarding auditors, the researcher suggests that Ethiopian share company law should establish auditing standards that should be observed when auditors undertakes their auditing functions.

\section{Bibliography}

\section{Books and Articles}

1) Berle A., and G., Means, The modern corporation and private property, MacMillan, New York,

2) Armour John, Hansmann Henry, Kraakman Reinier, (2009), The Essential Elements of Corporate Law: what is corporate law? Discussion Paper No. 643, Harvard Law School, Cambridge,

3) Al-Najjar, B. (2010), Corporate governance and institutional ownership,

4) Brietzke Paul, (1974), 'Private Law in Ethiopia' 18 Journal of African Law,

5) Claessens S. and Bergloef E., (September 2004), Corporate Governance and Enforcement, World Bank Policy Research Working Paper No. 3409,

6) Clarke Thomas, (2007), International Corporate Governance: A Comparative Approach,

7) Davies Paul, (2010), Introduction to Company law, (2 $2^{\text {nd }}$ ed.), University of Oxford,

8) Dine Janet, (2005), Company Law (5th ed.) Pal grave Macmillan,

9) Du Plessis Jeans Jacques, Hargovan Anil and Bagaric Mirko, (20110, Principles of Contemporary Corporate Governance ( $2^{\text {nd }}$ ed. Cambridge University Press, New York)

10) Fekadu Petros G., (2010), 'Emerging Separation of Ownership and Control in Ethiopia Share Companies: Legal and Policy Implications' vol. 4, No. 1, Mizan Law Review,

11) Fernando A.C., (2006), Corporate Governance, Principles policies and practices, Pearson Education, India,

12) Freeman E. R., Strategic Management: A Stakeholder Approach,

13) Gebeyaw Simachew, (2012), A Critical Analysis of the Ethiopian Commercial Code in Light of OECD Principles of Corporate Governance,

14) Getahun S., (2010), 'Revisiting Company Law the Advent of Ethiopian Commodity Exchange' vol. 4, No. 1, Mizan Law Review,

15) Greenfield Kent, (2007), The Failure of Corporate Law, University of Chicago Press,

16) Griffin Stephen, (2000), Economy and Law: Fundamental Principles ( $3^{\text {rd }}$ ed.) Pearson Edu. Limited,

17) Gurria Angel, (Sep. 2015), G20/OECD Principles of Corporate Governance,

18) Gyamerah S., (2016), Listed International Journal of Advanced Multidisciplinary Research Volume 3, Issue 11 ,

19) Hamilton A. Booz, (Jan 2007), Ethiopia Commercial Law and Institutional Reform and Trade Diagnostic, USAID,

20) Ho. Harper Virginia, (2010), “Enlightened Shareholders Value”: Corporate Governance Beyond the Shareholders and Stakeholders Divide', 36 Journal of Corporation Law,

21) Howell, E. Kerry, (2007), A Review of the two main competing models of corporate governance: The Shareholder ship Model versus the Stakeholder ship Model, Vol.5, Issues 1,

22) Hussein Ahmed Tura, (2012), Overview of Corporate Governance in Ethiopia: The Role, Composition and Remuneration of Board of Directors in Share Companies., Vol.6, No.1,

23) Jesover Fianna and Kirkpatrick Grant, (2005), 'The Revised OECD Principles of Corporate governance their Relevance to non-OECD Countries.'

24) Kirkpatrick Grant, (2004), 'Improving Corporate Governance Standards: The Work of the EOCD and the Principles.'

25) Klein A. William and Coffee, (2008), Business Organizations and Finance: legal and principles (10 ${ }^{\text {th }}$ ed.), Thomson West, 
26) Mallin A. Christine, (2007), Corporate Governance, (2 ${ }^{\text {nd }}$ ed.), Oxford University Press,

27) Metzger B. M., (2002), Business Law and the Regulatory Environment: concepts and cases (8 ${ }^{\text {th }}$ ed.) Irwin Inc., USA,

28) Minga Negash, (2013), Corporate Governance and Ownership Structure: The Case of Ethiopia,

29) P.C. Oman, (2001), Corporate Governance and National Development,

30) R. Freeman, Strategic Management: A Stakeholder Approach, Cambridge, UK: Cambridge University Press

31) Shade Joseph, (2006), Business Associations in a nutshell (2nd ed.) Thomson/West USA,

32) Wymeersch Eddy, (June 2005), Enforcement of Corporate Governance Codes.

\section{Legislations}

1) Commercial Code of the Emperor of Ethiopia, 1960, Neg. Gaz, year 9 $9^{\text {th }}$, No.3, Proclamation No.166 of 1960.

2) European Model Company Act (EMCA).

3) OECD Principles of Corporate Governance Framework (1999).

4) OECD Principles of Corporate Governance Framework (Revised 2004).

5) UK Company Act of 2006. 